\title{
Nedd5, a mammalian septin, is a novel cytoskeletal component interacting with actin-based structures
}

\author{
Makoto Kinoshita, ${ }^{1,6}$ Sharad Kumar, ${ }^{4}$ Akira Mizoguchi, ${ }^{2}$ Chizuka Ide, ${ }^{2}$ Ayae Kinoshita, ${ }^{3}$ \\ Tokuko Haraguchi, ${ }^{5}$ Yasushi Hiraoka, ${ }^{5}$ and Makoto Noda ${ }^{1}$
}

Departments of ${ }^{1}$ Molecular Oncology, ${ }^{2}$ Anatomy and Neurobiology, and ${ }^{3}$ Neurology, Graduate School of Medicine, Kyoto University, Kyoto 606, Japan; ${ }^{4}$ Hanson Centre for Cancer Research, Institute of Medical and Veterinary Science, Adelaide, SA5000, Australia; ${ }^{5}$ Kansai Advanced Research Center, Communications Research Laboratory, Kobe 651-24, Japan

\begin{abstract}
The mouse Nedd5 gene encodes a 41.5-kD GTPase similar to the Saccharomyces and Drosophila septins essential for cytokinesis. Nedd5 accumulates near the contractile ring from anaphase through telophase, and finally condenses into the midbody. Microinjection of anti-Nedd5 antibody interferes with cytokinesis, giving rise to binucleated cells. In interphase and postmitotic cells, Nedd5 localizes to fibrous or granular structures depending on the growth state of the cell. The Nedd5-containing fibers are disrupted by microinjection of GTP $\gamma$ S and by Nedd5 mutants lacking GTP-binding activity, implying that GTP hydrolysis is required for its assembly. The Nedd5-containing fibers also appear to physically contact actin bundles and focal adhesion complexes and are disrupted by cytochalasin D, C3 exoenzyme, and serum starvation, suggesting a functional interaction with the actin-based cytoskeletal systems in interphase cells.
\end{abstract}

[Key Words: GTPase; cytokinesis; stress fiber; focal adhesion; neural development]

Received March 3, 1997; revised version accepted May 6, 1997.

Molecular and genetic studies in yeast and fruit fly have revealed the existence of a novel class of cytoskeletal components, septins, which constitute an evolutionarily conserved GTPase family. Loss-of-function mutants in any of the four septin genes in Saccharomyces cerevisiae, $C D C 3, C D C 10, C D C 11$, and $C D C 12$, are deficient in the $10-\mathrm{nm}$ "neck filaments" that normally localize beneath the cleavage furrow between mother and bud (Byers and Goetsch 1976; for review, see Byers 1981), and give rise to multinucleated cells with abnormal bud growth at restrictive temperature (Hartwell 1971; for review, see Pringle and Hartwell 1981). Localization of each gene product to the cleavage furrow of the wild-type strain has also been demonstrated, establishing that they are the constituent of the bud neck filament (Haarer and Pringle 1987; Ford and Pringle 1991; Kim et al. 1991). Similarly, a mutation in a Drosophila septin gene, pnut, leads to a lethal phenotype with multinucleated cells in the larval tissues (Neufeld and Rubin 1994). Pnut and another Drosophila septin, Sep1, colocalize near the contractile ring in dividing cells (Neufeld and Rubin 1994; Fares et al. 1995). Recently, the three Drosophila septins, Pnut, Sep1, and Sep2, have been purified and their GTPase activity and ability to heteropolymerize to form a 7-nm filament in vitro were demonstrated (Field et al.

${ }^{6}$ Corresponding author.

E-MAIL mkinoshi@virus.kyoto-u.ac.jp; FAX 81-75-751-4159.
1996). These data suggest that septin filaments may play a common role in cytokinesis in both unicellular and multicellular organisms.

In an attempt to elucidate molecular mechanisms involved in neural development, we isolated a series of genes, named Nedd1-10, that are highly expressed in mouse neuronal precursor cells (NPC) and down-regulated in adult brain (Kumar et al. 1992). We found that one such gene, Nedd5, belongs to the growing family of septins. At least five mammalian septin genes, Diff6 (Nottenburg et al. 1990), H5 (Kato 1990, 1992), and Nedd5 (Kumar et al. 1992) in mouse, and hCDC10 (Nakatsuru et al. 1994) and KIAA0158 (Nagase et al. 1995) in human, have been isolated so far, but their products remain uncharacterized. Here we report on the structure, expression, subcellular localization, and possible functions of the Nedd5 gene and its product in mammalian cells.

Results

Cloning and structure of Nedd5 cDNA

In a previous subtraction screening for developmentally down-regulated genes in mouse brain, a cDNA fragment corresponding to the $3^{\prime}$-terminal 240 bases of Nedd5 mRNA, 4D12, was isolated (Kumar et al. 1992). Because the 4D12 cDNA detects mRNA of $\sim 3.5 \mathrm{~kb}$ in Northern blot analyses (see below), this probe was used to screen 
mouse cDNA libraries for the full-length cDNA, and a sequence of 3175 bases was isolated (GenBank accession no. D49382). The first in-frame ATG in a good context for mammalian translation initiation (Kozak 1986) is preceded by an in-frame stop codon located 21 bases upstream. The open reading frame of 1083 bases encodes a polypeptide of 361 amino acids with a predicted isoelectric point of 6.09 and a molecular mass of $41.5 \mathrm{kD}$ (Fig. 1A), which is consistent with the results of transcription/translation of the cDNA in vitro (data not shown) and immunoblot analysis (see below). The 3' untranslated region contains six destabilization signals (ATTTA) (Wilson and Treisman 1988) and a polyade-
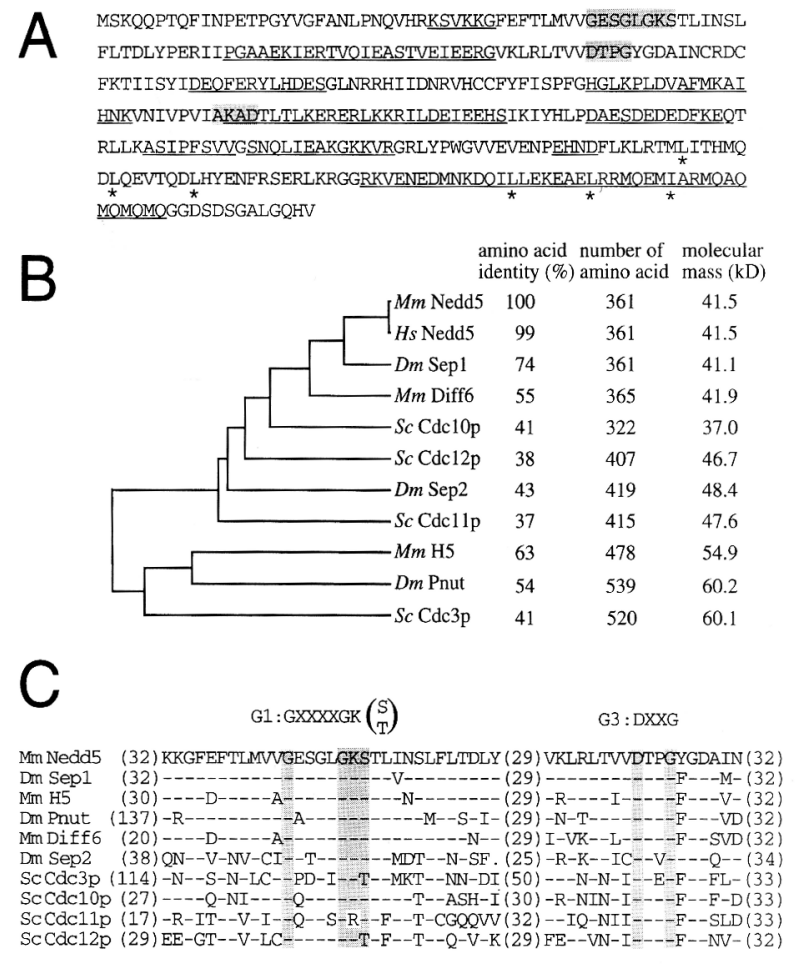

$$
\mathrm{G} 4: \mathrm{XKXD}
$$

Mm Nedd5 DNRVHCCFYFISPFGHGLKPLDVAFMKAIHNKVNIVPVIAKADTLTLKERERLKKRIL ( 161

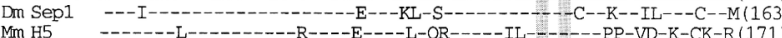
Dm H5

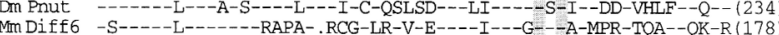

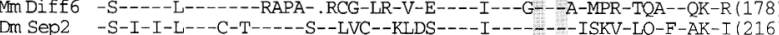

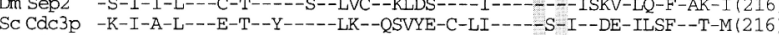
SCCdc10p -T---AIL--LQ-N-KE-SR---EAL-RLTEIA-VI---G-S-----D--TEFREL-Q(125) SCCdc11p -G----L-L-N-T----EI--E-IRQLGSL---I--S-S-S-MD-LKLN--L-M (226)

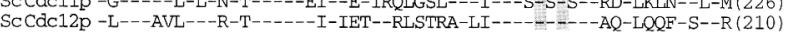

Figure 1. Nedd5 belongs to the septin family. $|A|$ Amino acid sequence of mouse Nedd5. The GTPase motifs are shaded. The predicted $\alpha$-helical domains are underlined. Asterisks denote the interrupted repeat of leucine or isoleucine. $(B)$ Phylogenetic tree of the septin family. The lengths of horizontal bars represent relative distance in molecular evolution. The putative product of KIAA0158 (Nagase et al. 1995) is labeled as Hs Nedd5. (C) Alignment of the mammalian, fruit fly, and yeast septins around the conserved GTPase motifs. Each amino acid identical to that of mouse Nedd5 is designated by a dash. The numbers of flanking amino acid residues are given in the parentheses. nylation signal (AATAAA) located 26 bases upstream of the poly(A) initiation site.

\section{Nedd5 encodes a member of the septin family}

A database search revealed that the putative Nedd 5 product shares similarities with yeast, fruit fly, and mammalian septins (Fig. 1B). The Nedd5 protein contains a set of consensus motifs found in GTPases (Saraste et al. 1990): The G1, G3, and G4 regions are highly conserved in the septin family but are distinct from those found in other GTPase subfamilies (Bourne et al. 1991) (Fig. 1A,C). Secondary structure prediction (Chou and Fasman 1978) indicated a possible $\alpha$-helix near the carboxyl terminus of Nedd5. This region also contains an interrupted leucine/ isoleucine repeat at every seventh amino acid residue (Fig. 1A), which may form a coiled-coil structure (Lupas et al. 1991) as suggested in most of the other septins (Flescher et al. 1993; Neufeld and Rubin 1994; Fares et al. 1995, 1996).

\section{Expression of Nedd5 mRNA}

A cDNA probe containing the entire open reading frame detected a single band of $\sim 3.5 \mathrm{~kb}$ in Northern blot analysis with mouse tissues (Fig. 2A). The intensity of this band gradually decreases during embryonic and postnatal brain development. In situ hybridization revealed that Nedd5 was ubiquitously expressed in embryos and down-regulated in the majority of neuronal populations in the adult brain (Fig. 2B). Nedd5 mRNA was detected in all adult tissues and cell lines examined, such as PCC4 (mouse embryonal carcinoma), CTLL2 (mouse Tcell leukemia), C6 (rat astrocytoma), PC12 (rat pheochromocytoma), $\mathrm{HeLa}, \mathrm{SiHa}$ (human uterine carcinoma), and HT1080 (human fibrosarcoma) (Fig. 2C; data not shown).

\section{Characterization of anti-Nedd5 antibodies}

We raised rabbit antisera against Nedd5 using two antigens: (1) a synthetic peptide, G2, corresponding to residues K74-T85 conserved between mouse and human proteins, and (2) a recombinant polypeptide, N5C, corresponding to a carboxy-terminal portion (R303-V361) of mouse Nedd5. The authenticity of each affinity-purified antibody was tested by immunoblot analysis using lysates of a human cell line SiHa stably transfected with mouse Nedd5 cDNA. Anti-G2 antibody 6 and anti-N5C antibody 11 detected a single band of $41-42 \mathrm{kD}$ that was more intense in the Nedd5-transfected cells than in vector-transfected cells and not detected with the preimmune serum or antibodies preadsorbed with excess amounts of the antigens (data not shown). The size of this band agrees with the predicted molecular masses (41.5 kD) of mouse Nedd5 and its human counterpart encoded by KIAA0158 (Fig. 2D). These results indicate that antibodies 6 and 11 can recognize both mouse Nedd 5 and its human counterpart. 
A
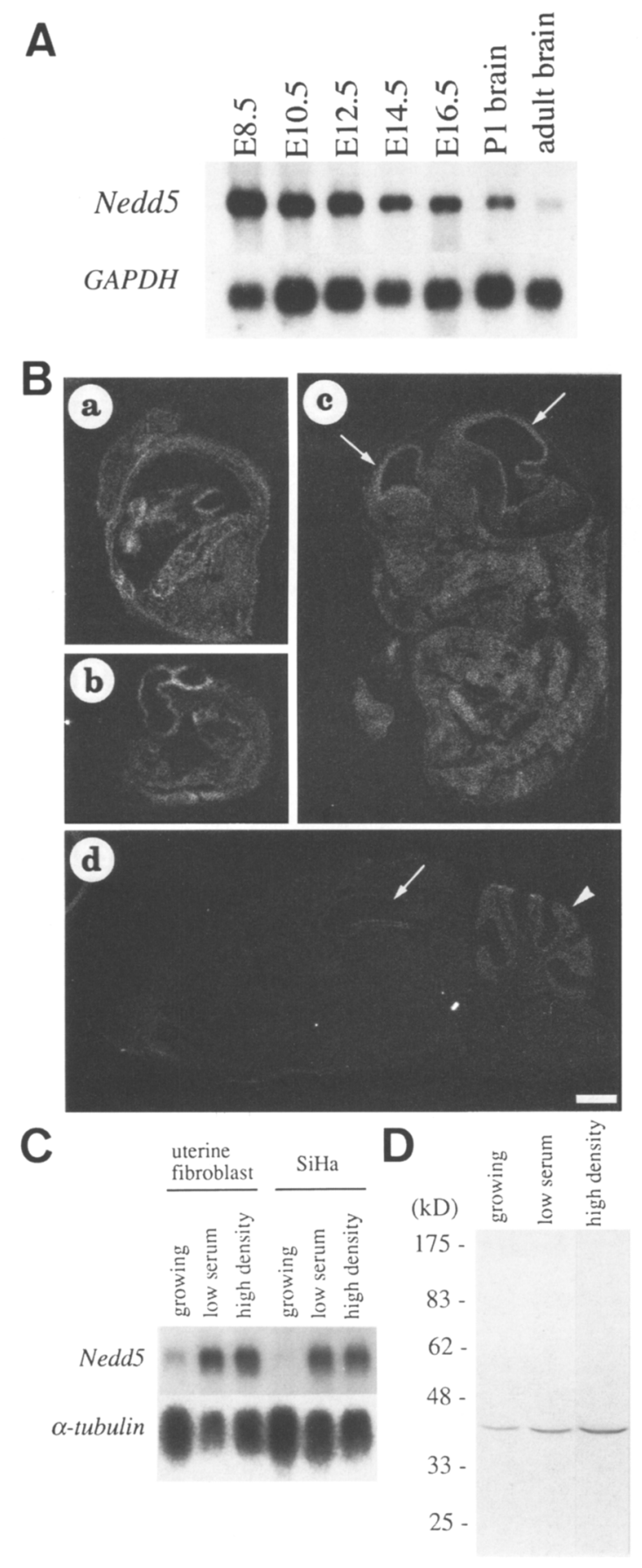

\section{Subcellular localization of Nedd5 during cytokinesis}

Subcellular localization of Nedd5 during cytokinesis was examined on immunostained $\mathrm{SiHa}$ cells by serial optical sectioning followed by image processing for deconvolution. Nedd5 localized to the plasma membrane around the contractile ring early in telophase (Fig. $3 \mathrm{Aa}-\mathrm{c}$ ) and in late telophase concentrated in the midbody, where tubulin is also localized (Fig. 3Ad-f). Accumulation of Nedd5 near the actin-based contractile ring in anaphase and telophase was also confirmed in HeLa, NIH-3T3, and
Figure 2. Expression of Nedd5 and its product. (A) Northern blot showing the gradual decrease of Nedd5 expression during mouse embryonic development and postnatal brain development. Each lane contains $2.5 \mu \mathrm{g}$ poly $(\mathrm{A})^{+}$RNA from the whole embryo [embryonic day (E) 8.5-16.5] or from the brains of newborn [postnatal day (P) 1] or adult mice. (B) Expression of Nedd5 in an E9.5 embryo in utero (a) and parasagittal sections of E10.5 (b) and E13.5 (c) embryos detected by in situ hybridization. The signal appears ubiquitous and relatively intense in the ventricular zone of the brain (arrows). (d) A parasagittal section of an adult brain showing the down-regulated expression of Nedd5. Note the limited expression in the hippocampus (arrow) and cerebellar cortex (arrowhead). Bar, $1 \mathrm{~mm}$. (C) Northern blot showing the up-regulation of Nedd5 in cells maintained under low serum concentration or at high density, as compared with rapidly growing cells. Each lane contains $5 \mu \mathrm{g}$ of poly $(\mathrm{A})^{+}$RNA from primary human uterine fibroblast or SiHa cells. (D) Immunoblot analysis of the $\mathrm{SiHa}$ cell samples shown in $C$. Each lane contains $22.5 \mu \mathrm{g}$ of total protein.

N18 cells (Fig. 3Da-f; data not shown). We also recorded sequential images, from anaphase through interphase, of HeLa cells mildly expressing Nedd5 fused with the $A e$ quorea green fluorescent protein (GFP) 16-48 hr after transfection. The Nedd5-GFP fusion protein was observed as a gradually condensing band surrounding the equator of an anaphase cell prior to the onset of cytokinesis (Figure 3BO,1), which then rapidly contracted and further condensed into the midbody. These results are consistent with the immunocytochemical data in fixed cells (Fig. 3A,Db,e), and suggest that Nedd5-GFP behaves like endogenous Nedd5 at least at these levels of resolution and time span. They also provide additional evidence for the authenticity of the antibodies used in this study.

\section{Interference of cytokinesis by anti-Nedd5 antibody}

To analyze the function of Nedd5 in cytokinesis, the anti-Nedd5 antibodies were microinjected into HeLa cells in late anaphase to early telophase. Injection of antibody 6 resulted in (1) immediate regression of the cleavage furrow $(n=5 / 20$; Fig. $3 \mathrm{C}$, top $)$, (2) persistent cytoplasmic connection between the daughter cells for $>2.5 \mathrm{hr}(n=8 / 20)$, which in three cases produced binucleated cells (Fig. 3C, bottom), or (3) completion of cytokinesis within $2.5 \mathrm{hr}$ after injection $(n=7 / 20)$. On the other hand, cytokinesis was completed within $2.5 \mathrm{hr}$ in all of the cells injected with dialyzed preimmune se$\operatorname{rum}(n=6)$ or antibody $11(n=6)$ (data not shown). In the antibody 6-injected binucleated cells, normal distribution of Nedd5 was perturbed, whereas cortical actin organization remained largely intact (Fig. 3Dg-i). Because antibody 6 modifies the biochemical activities of Nedd 5 (see below), we interpret these results as an indication that Nedd5 plays an essential role during cytokinesis.

\section{Subcellular localization of Nedd5 in interphase and postmitotic cells}

In interphase fibroblasts, Nedd5 immunoreactivity was 

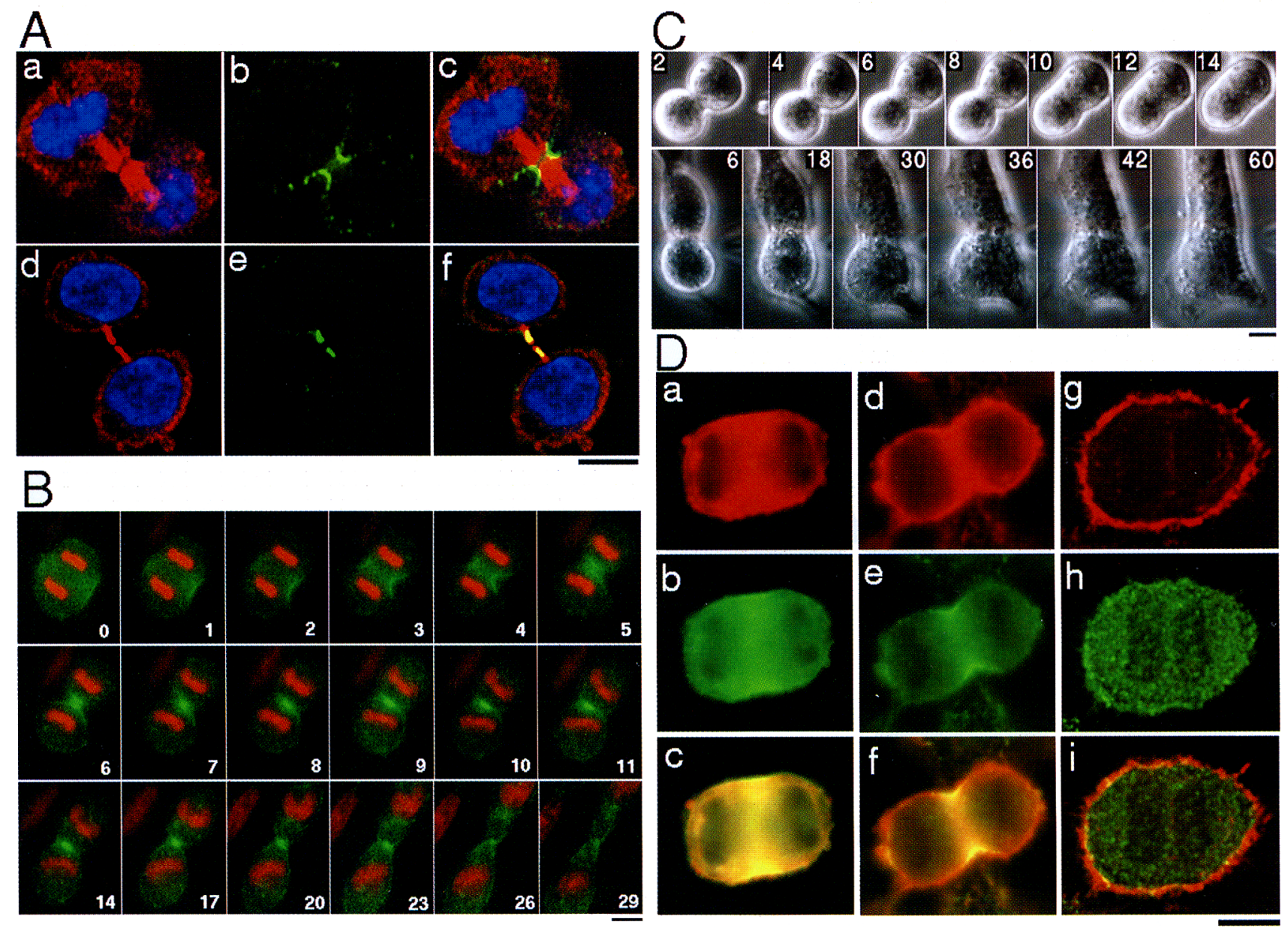

Figure 3. Dynamics and possible functions of Nedd5 in cytokinesis. $|A|$ Computer-processed optical sections of dividing SiHa cells stained for $\alpha$-tubulin (red), nuclear DNA (blue), and Nedd5 (green). (a) The organization of the mitotic spindle and nuclei in early telophase. (b) Nedd5 is localized near the contractile ring. (c) The superimposed image of $a$ and $b .(d)$ Microtubules and the nuclei in late telophase. $(e)$ Nedd5 is concentrated near the midbody. $(f)$ The superimposed image of $d$ and $e$; note the overlapped signals (yellow) of $\alpha$-tubulin and Nedd5 in the midbody. $(B)$ Time-lapse fluorescence images of Nedd5-GFP fusion protein (green) and chromosomal DNA (red) in HeLa cells from anaphase through interphase. The numbers denote the time (min). See text for detail. $(C$, top $\mid$ Time-lapse phase-contrast images of a cell in which the cleavage furrow regressed after microinjection with anti-Nedd5 antibody 6. (Bottom) Another example of abortive cytokinesis after antibody injection. In this case, cytokinesis seemed to be severely retarded and the cytoplasmic connection between the daughter cells persisted for a considerable period of time before they eventually fused together to form a binucleated cell. The numbers denote the time after injection $(\mathrm{min}) .(D)$ Distribution of actin $(a, d, g), \mathrm{Nedd} 5(b, e, h)$, and both $(c, f, i)$ in a noninjected HeLa cell in anaphase $(a-c)$ or telophase $(d-f)$ and deconvoluted images of a binucleated cell 30 min after injection of antibody 6 during telophase $(g-i)$. Nedd5 localized near the actin-based contractile ring $(a, d)$ from anaphase through telophase $(b, e)$. Note the apparently intact cortical actin bundles $(g)$ and granular signals composed of both endogenous Nedd5 immunostained with antibody 11 and injected antibody 6 that were detected by FITC-labeled anti-rabbit secondary antibody $(h)$. Bars, $10 \mu \mathrm{m}$.

detected in granular and fibrous structures localized close to actin-based structures in filopodia, stress fibers, and lamellipodia (Fig. 4A-C,E-G). Interestingly, the Nedd 5 antibodies partially decorated the stress fibers and fine network of actin filament (Fig. 4B,E-G). Some of the Nedd5-containing fibrous structures also appeared to be connected to focal adhesion complexes where actin stress fibers are anchored (Fig. 4H). No apparent colocalization or close apposition between Nedd 5 and other major cytoskeletal components, such as tubulin and vimentin, was observed during interphase in NIH-3T3 cells (data not shown). In postmitotic, differentiating N18 neuroblastoma cells, Nedd5 is also found in fibrous and granular forms in the neurites (Fig. 4D). The Nedd5-containing fibers were in close apposition to the actin filaments, which was most obvious in the microspikes.

\section{Effects of growth states and transformation on expression and distribution of Nedd5 protein}

Because Nedd5 is highly expressed in embryo and implicated in cell division, we expected to detect higher ex- 

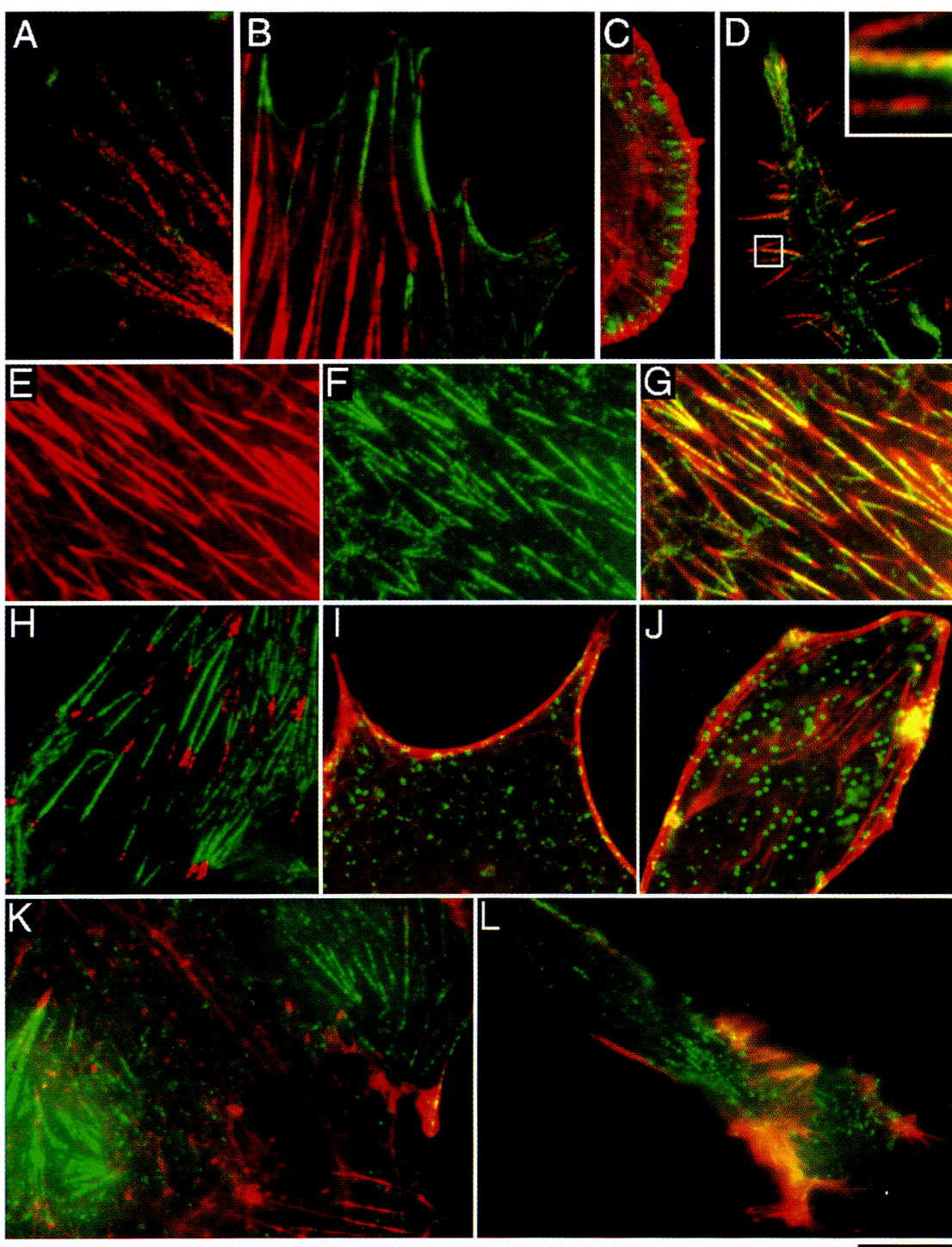

Figure 4. Localization of Nedd5 in interphase and postmitotic cells. Double stain ing of NIH-3T3 (A-C, E-G) or N18 cells (D) for Nedd5 (green) and $\mathrm{F}$ actin (red). $(A)$ Nedd5-staining is amorphous or granular in pseudopodia. (B) Fibrous structures containing Nedd 5 are aligned along actin stress fibers and the cell periphery. $(C)$ Nedd5 is enriched in the radial ribs of lamellipodia which is surrounded by $\mathrm{F}$ actin. $(D)$ Nedd5containing filaments and $\mathrm{F}$ actin in neurites of a differentiating N18 cell. The two filaments appear to run in close apposition to, and partially overlap with, each other in the neurites. The higher magnification of the boxed area is shown in the inset. $(E)$ Well-organized actin stress fibers in a growing cell. $(F)$ Nedd5-containing structures in the same field. $|G|$ The superimposed image of $E$ and $F$. Note that Nedd5 partially decorates actin stress fibers where phalloidin staining appears slightly weaker. $(H)$ Double staining of NIH-3T3 cells for Nedd5 (green) and vinculin (red). Nedd5 appears to be anchored to focal adhesions. $(I, I)$ Double staining of NIH-3T3 cells for F actin (red) and Nedd5 (green) 10 days after serum starvation, when most of the actin stress fibers have been disrupted and the fibrous form of Nedd 5 has been replaced by the granular form (see also Fig. 7F). $(K, L)$ CREF cells harboring regulatable ras $^{\mathrm{G} 12 \mathrm{~V}}$ stained for Nedd5 (green) and $\mathrm{F}$ actin (red). $(K)$ When ras is turned off, the cells exhibit polygonal shape with well-developed actin stress fibers and the fibrous distribution of Nedd5. $(L)$ When ras is turned on, the cells are transformed with loss of stress fibers and shortening of the fibrous Nedd5. Bar, $10 \mu \mathrm{m}$ except for the inset. pression in proliferating cells than in quiescent cells. However, Nedd5 mRNA and protein were more abundant in primary human fibroblasts and $\mathrm{SiHa}$ cells that were growth-arrested, either by serum starvation or by contact inhibition, than in cells that were actively proliferating (Fig. 2C,D).

In interphase NIH-3T3 cells under regular culture conditions, stress fibers and focal adhesion complexes were well organized, and the fibrous structures containing Nedd5 partially overlap with actin stress fibers, as mentioned above (Fig. 4B,E-G). Ten days after serum starvation, when most of the actin stress fibers, but not the cortical actin bundles, have dispersed (Burridge et al. 1988; Ridley and Hall 1992), virtually all the Nedd5-containing fibers had also disappeared and Nedd5 was found almost exclusively in the granular form (Fig. 4I,J).

In a rat embryo fibroblast cell line stably transfected with ras $^{\mathrm{G} 12 \mathrm{~V}}$ under a regulatable promoter (Gossen and Bujard 1992), the well-developed stress fibers and the fi- brous distribution of Nedd 5 were observed when the promoter was turned off with tetracycline (Fig. 4K). Without tetracycline treatment (i.e., $\operatorname{ras}^{\mathrm{G} 12 \mathrm{~V}}$-induced), the cells were morphologically transformed, and a shortening of the Nedd5-containing fibers were observed, concomitantly with the loss of actin stress fibers (Fig. 4L) and focal adhesions (data not shown).

\section{Electron microscopic observation of Nedd5-containing structures}

In immunoelectron microscopic observations of NIH3T3 fibroblasts with antibody 11, the signals were mainly detected as single arrays of gold particles (Fig. $5 A, B \mid$, indicating that Nedd5 localizes to filamentous structures. The immunoreactive, straight or curved lines were frequently found in peripheral cytoplasm beneath the plasma membrane. Although their lengths were 0.2$1.0 \mu \mathrm{m}$, the entire length of the filaments may be under- 
Figure 5. Electron-microscopic observation of the Nedd5-containing structures. Electron micrographs of the NIH-3T3 cells $(A, B)$ and SiHa cells $(C, D)$ treated with antibody 11 and a gold-conjugated secondary antibody. $(A)$ Nedd5-immunoreactive signals in the cell periphery are detected as single arrays of gold particles (arrowheads), some of which seem closely associated with the cortical actin bundles. (B) A single Nedd5-immunoreactive line at a higher magnification (arrowhead). $|C, D|$ The immunoreactive signals are concentrated in various regions of the plasma membrane (arrowheads), filopodia (arrows), and cytoplasm $(\mathrm{C})$ but rare in the nucleus $(\mathrm{N})$ of SiHa cells. Bars, $0.5 \mathrm{~mm}$.

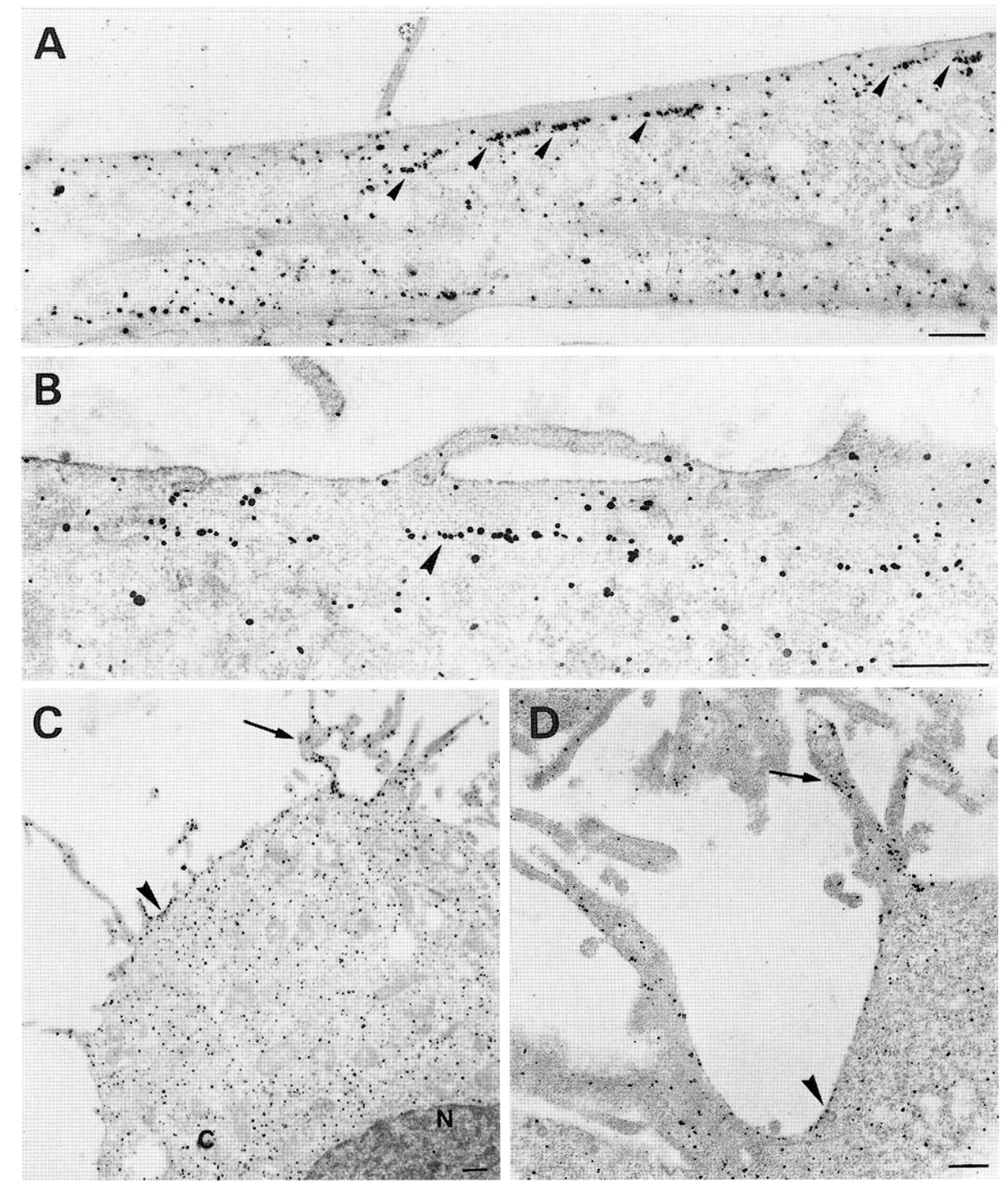

represented because of severance by the ultrathin sectioning at $0.05 \mu \mathrm{m}$. Detailed morphology of the filaments is difficult to examine because the gold particles densely decorate the underlying structure; however, it is clear that the Nedd5-containing lines often ran in parallel, or in close apposition, to the cortical actin filaments that outnumber the Nedd5-immunoreactive lines. This observation is consistent with the immunofluorescence data described above.

In the epithelial tumor-derived SiHa cells, Nedd5 was present as short filaments or small clusters beneath the plasma membrane and in filopodia (Fig. 5C,D). Dispersed signals, which might correspond to the granular form in the fluorescent micrographs, were also found throughout the cytoplasm but were rare in the nucleus.

\section{GTPase activity of Nedd5}

To evaluate the importance of GTPase activity for the functions of Nedd5, we generated Nedd5 mutants each carrying a single amino acid substitution at a residue conserved among the known mammalian septins. The mutations, G47V, Q125L, and S51N, were designed based on the well-characterized Ras mutants with reduced GTPase activity (G13V, Q61L) and dominant negative activity (S17N), respectively (for review, see Polakis and McCormick 1993). We first examined the biochemical activities of bacterially expressed glutathione $S$-transferase (GST) fusion proteins. The wild type GSTNedd5 showed strong GTP-binding and -hydrolyzing activities as expected. In contrast, all the mutant proteins exhibited no detectable GTP-binding activities under the experimental conditions we employed (Fig. 6A). Interestingly, antibody 6 , directed against a region of Nedd 5 corresponding to the effector domain of Ras, promoted the GTPase activity of the wild-type GST-Nedd5 in a dosedependent manner without affecting its GTP-binding activity (Fig. 6B). In contrast, antibody 11 showed no effects on either GTP-binding or -hydrolyzing activities. This may account for our finding that this antibody showed no effect on cytokinesis (see above).

The same set of mutant proteins fused to GFP were transiently expressed in HeLa cells, and the behaviors of 

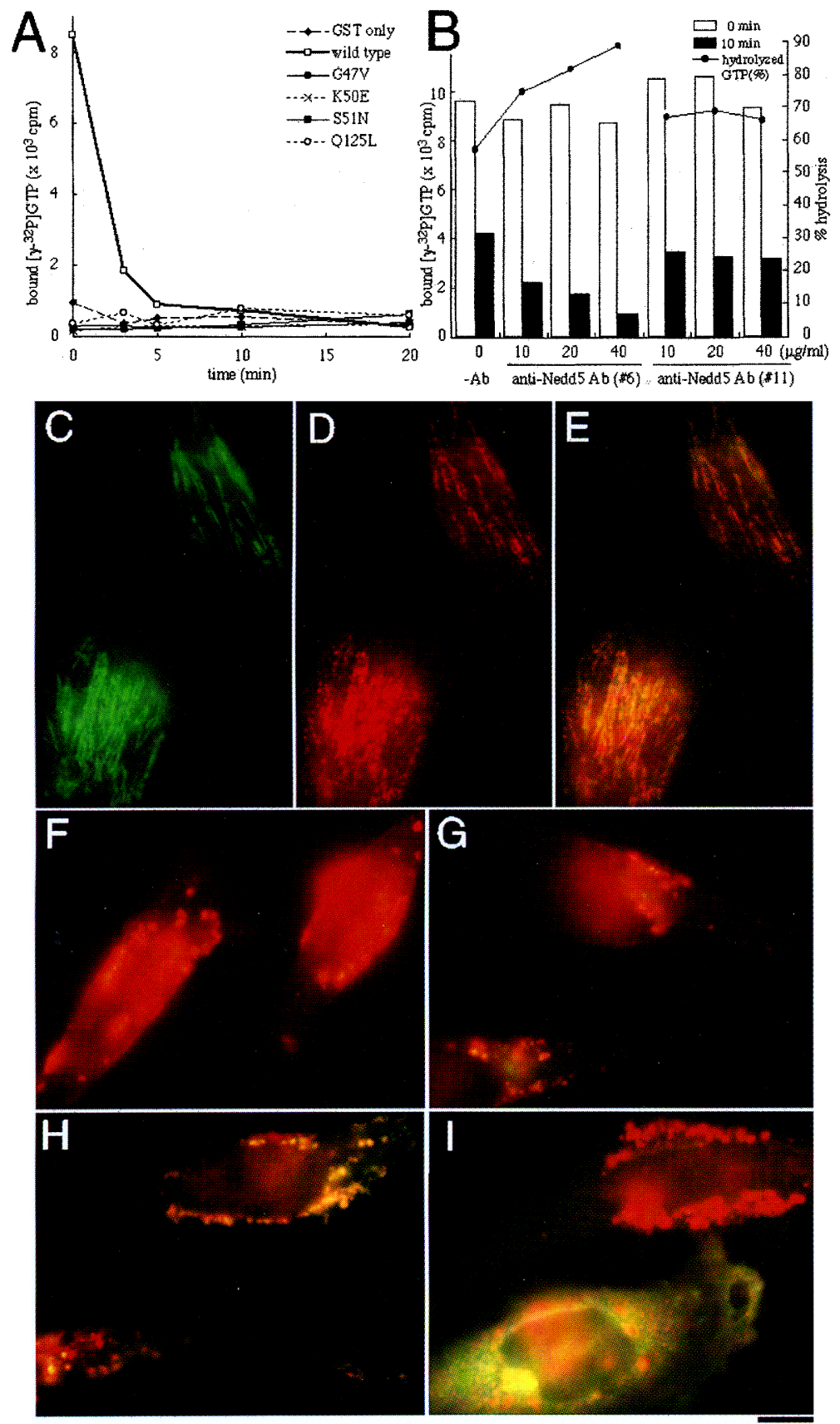

Figure 6. GTPase activity is essential for the normal distribution of Nedd5. (A) GTP-binding activity and the time course of GTP hydrolysis by GST, GSTfused Nedd5, and its mutants. Each of the four missense mutations introduced in the conserved GTPase motifs of Nedd5 abolished its GTP-binding activity. $(B)$ Effects of the antibodies directed against a possible $\mathrm{G}_{2}$ domain $(6)$ and a carboxy-terminal portion $(11)$ of Nedd5 on the GTP-binding and -hydrolyzing activities of the GST-Nedd5. Open and solid bars represent the bound $\left[\gamma^{-}{ }^{32} \mathrm{P}\right] \mathrm{GTP}$ measured at 0 and $10 \mathrm{~min}$ after incubation at $37^{\circ} \mathrm{C}\left(\mathrm{B}_{0}\right.$ and $\left.\mathrm{B}_{10}\right)$, respectively (Ieft ordinate). The fraction of hydrolyzed GTP $\left[\left(\mathrm{B}_{0}-\mathrm{B}_{10}\right) /\right.$ $\mathrm{B}_{0}$ ) is plotted (right ordinate). Antibody 6 promoted GTP-hydrolysis by GST-Nedd5 in a dose-dependent manner without affecting its GTP-binding activity, whereas antibody 11 showed no detectable effects. $(C-I)$ Fluorescence images of fixed HeLa cells expressing wild-type $(C-E)$ or mutant $(F-I)$ Nedd5-GFP fusion proteins. $|C|$ The Nedd5-GFP signals. $(D)$ The total Nedd5 immunoreactivity, including both endogenous Nedd5 and Nedd5-GFP: visualized using antibody 11 and Texas Red-labeled secondary antibody. (E) The superimposed image of $C$ and $D$. Note the localization of Nedd5-GFP in the normal fibrous structures in interphase, which is indistinguishable from that of endogenous Nedd5. The superimposed images of Nedd5-GFP mutants (green) and the total Nedd5 immunoreactivity (red) in the cells transfected with G47V $(F)$, K50E $(G)$, S51N $(H)$, or Q125L $(I)$. In every case, the mutant Nedd5-GFP and the endogenous Nedd5 form large aggregates or localize diffusely in the cytoplasm. Yellow to orange colors indicate the colocalization of immunoreactivity and GFP. Bar, $10 \mu \mathrm{m}$. the endogenous Nedd5 and the Nedd5-GFP fusion proteins were examined. As expected, the wild-type Nedd5GFP protein, when mildly expressed, was found to colocalize with the endogenous Nedd5 protein mostly in the filamentous structures (Fig. 6C-E). On the other hand, all the mutant Nedd5-GFP proteins appeared to form large aggregates or localize diffusely throughout the cytoplasm (Fig. 6F-I). Importantly, all the mutant proteins appeared to interfere with the distribution of the endog. enous Nedd5 protein.

We also examined the effects of a nonhydrolyzable GTP analog, GTPyS, on the behavior of endogenous
Nedd 5 in HeLa cells. Within $1 \mathrm{hr}$ after microinjection of GTP $\gamma$ S, the fibrous distribution of Nedd5 was largely disrupted (Fig. 7D), whereas actin stress fibers appeared unaffected as has been reported previously (Redmond et al. 1994). These results suggest that the fibrous distribution of Nedd5 requires GTP hydrolysis.

Actin filament is essential for the fibrous distribution of Nedd5 in interphase cells

The funtional relationship between actin filaments and Nedd5-containing fibers was further examined by using 
Figure 7. Normal distribution of Nedd5 is dependent on GTP hydrolysis and actin bundles. (A) Concomitant disruption of actin stress fibers (red) and the fibrous Nedd5 (green) in HeLa cells incubated with $1 \mu \mathrm{g} / \mathrm{ml}$ cytochalasin $\mathrm{D}$ for 20 min. $(B)$ Intact actin stress fibers (red) and aggregated Nedd5(G47V)-GFP (green) in a transfected HeLa cell. $(C-E)$ Immunocytochemistry of HeLa cells microinjected with GTPyS or C3 exoenzyme with a marker dye (fluorescent dextran) into the cytoplasm. $(C) \mathrm{A}$ cell injected with the marker alone (orange) exhibited intact fibrous distribution of Nedd5 (green) similar to that seen in the adjacent, noninjected cell. $(D)$ Disruption of most of the fibrous Nedd5 staining (green) in the HeLa cells $1 \mathrm{hr}$ after injection of GTP $\gamma \mathrm{S}$ (top cell), whereas actin stress fibers (red) appear unaffected; compare with the adjacent, noninjected cell. $(E)$ Disruption of most of the fibrous Nedd5 staining (green) in HeLa cells $1 \mathrm{hr}$ after injection of C3 exoenzyme (top cell). (F) Reorganization of actin stress fibers (red) and Nedd5-containing fibers (green) within $10 \mathrm{~min}$ after serum stimulation in NIH-3T3 cells that had been cultured in low serum condition for 10 days (see Fig. 4I,J). Note the yellow fibers containing both $\mathrm{F}$ actin and Nedd5. $(G)$ When antibody 6 was microinjected 10 min before serum stimulation, formation of Nedd5-containing fibers was inhibited (the green granules represent the endogenous Nedd 5 immunostained with antibody 11 and injected antibody 6 , both of which were recognized by FITC-labeled secondary antibodyl, whereas actin stress fibers appear to be organized nor-
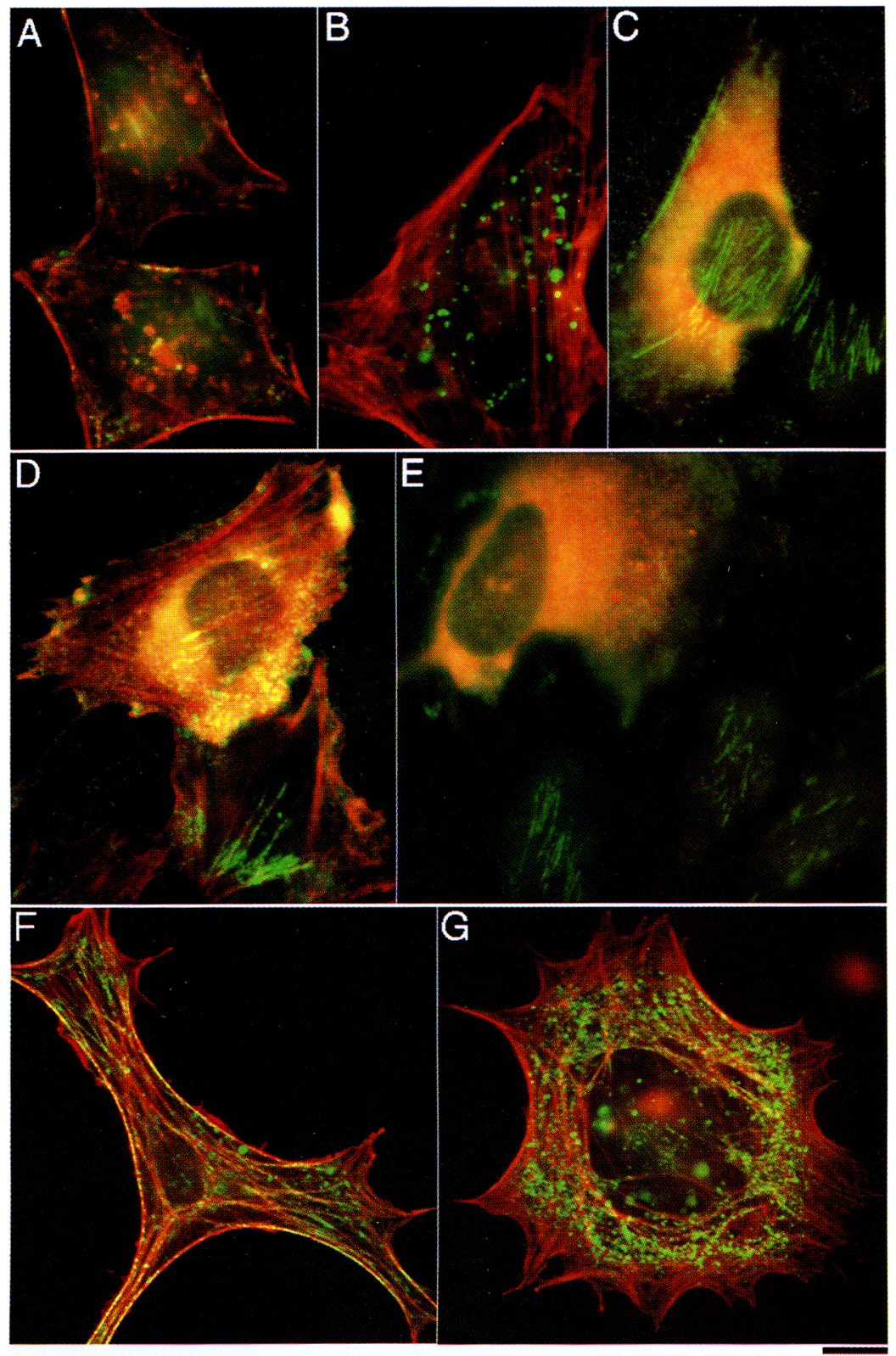
mally. Bar, $10 \mu \mathrm{m}$.

two reagents known to disrupt actin bundles. When HeLa cells were treated with cytochalasin D, which directly inhibits $\mathrm{F}$ actin formation, the fibrous distribution of Nedd5 as well as actin stress fibers were disrupted (Fig. 7A). Botulinus C3 exoenzyme, which is known to disturb F actin indirectly by inhibiting Rho protein (Ridley and Hall 1992), also severely disrupted both Nedd5containing fibers and actin stress fibers (Fig. 7E). Interestingly, however, the four mutant Nedd5-GFP fusion proteins (Fig. 7B; data not shown) and microinjection of antibody 6 (Fig. 7G) showed little effects on the integrity of actin stress fibers. Thus the fibrous distribution of Nedd5 seems to require intact actin stress fibers; however, a reverse scenario appears unlikely.

\section{Discussion}

In this study we have demonstrated that the ubiquitously expressed Nedd5 gene encodes a protein that belongs to the septin family of GTPases and localizes near the contractile ring during cytokinesis in mammalian cells. Similarity between the multinucleated phenotypes of the yeast and fruit fly septin mutants and the results of our antibody microinjection studies suggest that septins are essential for cytokinesis in a wide variety of organisms. Our preliminary experiments, however, indicated that mouse Nedd5 failed to complement any of the Saccharomyces mutants, CDC3, CDC10, CDC11, or CDC12 (M. Kinoshita, S. Kumar, and M. Noda, unpubl.); 
there may be no orthologous septins in phylogenetically distant species, possibly because of molecular coevolution (Cooper and Kiehart 1996; Longtine et al. 1996).

In addition to the widely recognized role for septins as scaffolds to determine the cleavage plane in cytokinesis (Chant 1996), we investigated the behavior of Nedd5 in other phases of the cell cycle: In interphase and postmitotic cells, Nedd5 protein localizes to the unique cytoplasmic fibrous and granular structures. Some of the Nedd5-containing fibers are in close apposition to, and partially overlapping with, cortical actin bundles and the actin filaments in microspikes, filopodia, lamellipodia, neurites, and stress fibers, where the actin-based contractile system is known to play a major role. At lightmicroscopic resolution, it appeared as if Nedd5 staining was predominant in some regions of the stress fiber, whereas $\mathrm{F}$ actin staining was predominant in other regions of the same contiguous stress fiber (Fig. 4B,E-G). This may suggest masking of phalloidin-binding sites on F actin by Nedd 5 . Immunoelectron microscopy also suggested that the Nedd5-containing filaments partially decorate the contiguous actin bundles. Furthermore, the possibility that Nedd5-containing fibers interact with, and act in conjunction with, actin bundles is suggested by the rapid, concomitant disruption of both the Nedd5containing fibers and actin stress fibers by cytochalasin $\mathrm{D}$ treatment. On the other hand, expression of the four mutant Nedd5-GFP proteins, microinjection of antibody 6 and GTP $\gamma$ S interfered with the fibrous distribution of Nedd5 without disturbing actin stress fibers. This indicates that although intact actin fibers appear to be requisite for the maintenance of Nedd5-containing fibers, these fibers are not required for the maintenance of actin stress fibers (Fig. 8).

Under the light microscope Nedd5-containing fibers appear to be connected with focal adhesions, and Nedd5 is enriched in the radial ribs of lamellipodia where focal adhesion complexes cluster (Burridge et al. 1988). The concomitant decrease in the Nedd5-containing fibers

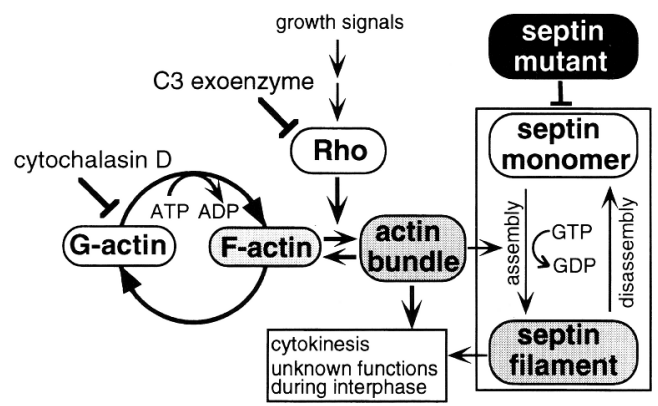

Figure 8. A proposed model for the regulation of septin filament assembly. Some parts of this model are based on the models for the Rho-actin system published previously (Machesky and Hall 1996) and for Drosophila septin assembly (Field et al. 1996). The thick and thin lines represent the well-established and postulated pathways, respectively. Black arrows indicate the molecular transitions or positive regulations. T-shaped arrows indicate inhibitory actions. (See text for details). and focal adhesions after serum starvation or transformation again suggests a functional interaction between the Nedd5 and actin systems. In addition, our preliminary experiments showed that GST-fused Nedd5, but not GST alone, cosedimented with purified $\mathrm{F}$ actin after ultracentrifugation (M. Kinoshita, T. Obinata, and $M$. Noda, unpubl.). Thus, Nedd5 monomer or the putative homodimer seems to directly bind to $\mathrm{F}$ actin without forming the septin heteropolymer complex (see below).

A cascade of signals transmitted by some of the small GTPases, including CDC42, Rac, and Rho, is known to regulate the configuration of the plasma membrane through actin/myosin-based contractile systems (for review, see Machesky and Hall 1996). In fact, some of these small GTPases are known to be essential for the assembly of stress fibers, focal adhesions, filopodia, lamellipodia (Ridley and Hall 1992; Nobes and Hall 1995), and the contractile ring (Kishi et al. 1993; Mabuchi et al. 1993), regions in the cell where Nedd5 is most concentrated. C3 exoenzyme interfered with the normal distribution of actin and Nedd5 in interphase (Fig. 7E) and also during cytokinesis (data not shown), suggesting that Rho stabilizes Nedd5-containing fibers, perhaps by stimulating the formation of actin bundles (Fig. 8). Alternatively, Rho may regulate the formation of both actin filaments and Nedd5-containing fibers independently.

Microinjection of GTP $\gamma$ S disrupted Nedd5-containing fibers, apparently leaving the integrity of actin stress fibers largely intact. Although GTP $\mathrm{S}$ p probably functions by affecting a number of cellular GTPases, the effects of the GTP-binding defective Nedd5 mutants support the hypothesis that GTP-binding and -hydrolysis by Nedd5 are required for its fibrous assembly. A model for Drosophila septin polymerization proposes that homodimerization of the three septin monomers and subsequent tandem heteropolymerization of the three septin dimers may form a unit complex, which is further assembled into filamentous structures (Field et al. 1996). This model suggests that the dominant effects of the Nedd5 mutants could be caused by their dimerization with endogenous Nedd5, and the inability of the mutant to bind and hydrolyze GTP would then block subsequent steps of complex formation or filament assembly (Fig. 8).

Our preliminary experiments using antibodies against mouse H5 and Diff6 indicated that they also localize near the contractile ring and that the three mammalian septins are mutually immunoprecipitable (M. Kinoshita, A. Kinoshita, and M. Noda, unpubl.). Thus, heteropolymer complexes, composed of Nedd5, H5, Diff6, and probably other septins, are highly likely to exist in mammalian cells as well as in Drosophila. The Drosophila septins form filaments in vitro in which a heterotrimer of the three septin homodimers constitutes a 26-nm subunit, and it may polymerize end to end in a polar fashion to form the 0.028- to 0.35- $\mu \mathrm{m}$ filaments (Field et al. 1996). Our electron microscopic study indicated that the Nedd5-containing filaments ranged $0.2-1.0 \mu \mathrm{m}$ in length, with $\sim 0.5 \mu \mathrm{m}$ the most frequent size. Thus, the dimensions of the Drosophila septin filaments in vitro 
and the mammalian septin filaments we detected in vivo are roughly comparable.

After serum starvation, the amounts of Nedd5 mRNA and protein increase and the granular form of Nedd 5 replaces the fibrous form. These data, along with our transformation experiments, suggest that the two forms of Nedd5-containing structures are in dynamic equilibrium, the ratio of which can change drastically depending on the growth state of the cells. In fact, dynamic reorganization of the fibrous Nedd5-GFP was also visualized by time-lapse observations in interphase cells (data not shown).

This and our previous studies (Kumar et al. 1992) demonstrate the expression of Nedd5 in the nervous systems and an elaborate network of Nedd5 in the neurites. A partial cDNA sequence corresponding to the rat Nedd5 gene has been classified as one of the genes whose expression levels change in PC12 cells upon nerve growth factor-induced differentiation (Lee et al. 1995). Another mammalian septin gene, mouse $H 5$, is also expressed in the embryonic brain (Kato 1990,1992). Drosophila septins are also enriched in the embryonic nervous systems (Neufeld and Rubin 1994; Fares et al. 1995). Moreover, our in situ hybridization and immunohistochemical data on adult mouse brain suggest that Nedd5 mRNA and/or protein are expressed in certain neurons in the hippocampus, stria terminalis, red nucleus, trigeminal ganglion, and retina and Purkinje cells in the cerebellum (M. Kinoshita, A. Kinoshita, S. Kumar, and M. Noda, unpubl.). Thus, functions of the septins in the developing and mature nervous systems constitute an important subject for future studies.

\section{Materials and methods}

\section{Cloning and structural analysis of Nedd5 cDNA}

NPC- and PCC4-derived CDNA libraries were screened with the mouse cDNA fragment 4D12 as described (Kumar et al. 1992,1994). Several overlapping Nedd5 cDNA fragments were sequenced (Sambrook et al. 1989), and the structural, homology and phylogenetic analyses were performed with the software BLAST, PEPTIDESTRUCTURE (Wisconsin Genetics Computer Group), and Geneworks (Intelligenetics).

\section{Northern blot analysis}

Poly $(\mathrm{A})^{+}$RNA ( 2.5 or $5 \mu \mathrm{g}$ ) was resolved in $1.2 \%$ agarose $/ 2.2 \mathrm{M}$ formaldehyde gels and transferred onto a nylon membrane, which was hybridized with ${ }^{32} \mathrm{P}$-labeled cDNA probe /clone N5.2.8 containing the entire open reading frame) in QuickHyb (Amersham) at $65^{\circ} \mathrm{C}$ for $2 \mathrm{hr}$, washed with $0.1 \times \mathrm{SSC}(15 \mathrm{~mm}$ $\mathrm{NaCl}, 1.5 \mathrm{~mm} \mathrm{Na}$-citrate, $\mathrm{pH}$ 7) at $60^{\circ} \mathrm{C}$, and autoradiographed. The same filters were reprobed with ${ }^{32} \mathrm{P}$-labeled rat glyceraldehyde 3-phosphate dehydrogenase (GAPDH) cDNA (Tso et al. 1985 ) or human $\alpha$-tubulin cDNA (Cowan et al. 1983).

\section{In situ hybridization}

Our procedure for in situ hybridization was described previously (Sazuka et al. 1992). In brief, mouse embryos and adult brains were cryostat-sectioned at $10 \mu \mathrm{m}$ and mounted on glass slides. After fixation with $4 \%$ paraformaldehyde and pretreat- ment, each section was incubated at $42^{\circ} \mathrm{C}$ for $12 \mathrm{hr}$ with a hy bridization buffer containing $10^{5} \mathrm{cpm}$ sense or antisense ${ }^{35} \mathrm{~S}$ labeled RNA probe transcribed from the N5.2.8 cDNA in vitro. After hybridization, the sections were treated with $10 \mathrm{mg} / \mathrm{ml}$ of RNase $\mathrm{A}$ at $37^{\circ} \mathrm{C}$ for $15 \mathrm{~min}$ and washed with $2 \times \operatorname{SSPE}(0.3 \mathrm{M}$ $\mathrm{NaCl}_{1} 30 \mathrm{~mm} \mathrm{NaH} \mathrm{PO}_{4}, 2 \mathrm{~mm}$ EDTA at $\left.\mathrm{pH} 7.4\right)$ at $42^{\circ} \mathrm{C}$ and then with $0.1 \times \mathrm{SSPE}$ at $50^{\circ} \mathrm{C}$. After dehydration, autoradiography was done with Hyperfilm $\beta$-max (Amersham) for 7 days.

\section{Antibodies}

As antigen, we employed a synthesized multiple antigen peptide (Tam et al. 1988), G2 (KIERTVQIEAST; residues 74-85 of mouse/human Nedd5), or a recombinant polypeptide N5C. $\mathrm{N} 5 \mathrm{C}$ is an oligohistidine-tagged carboxy-terminal 59 residues of mouse Nedd5 expressed using $\mathrm{pET}-14 \mathrm{~b}$ vector (Novagen) and purified by column chromatography with His-bind resin (Novagen). Nine rabbits were immunized with either G2 $(0.5 \mathrm{mg})$ or N5C $(1 \mathrm{mg})$ in Freund's complete adjuvant (Sigma). After boosting, the sera were collected and affinity purified using the antigens coupled with $\mathrm{CNBr}$-activated Sepharose 4B (Pharmacia). One of the anti-G2 antibodies (6) and one of the anti-N5C antibodies (11) were primarily used in this study.

\section{Immunoblot analysis}

We followed the standard protocols by Sambrook et al. (1989) with some modifications. In brief, mouse brain or cultured cells (see below) were homogenized in RIPA buffer and centrifuged at $15,000 \mathrm{rpm}$ for $0.5 \mathrm{hr}$. The supernatant was denatured in a reducing SDS buffer, resolved through $10 \%$ polyacrylamide gel, and transferred onto PVDF membrane (Micron Separations). The membrane was incubated overnight with the blocking buffer, $0.2 \%$ Tween 20 in Tris-buffered saline (TBST at pH 7.4) containing $1 \%$ bovine serum albumin (BSA), then incubated with each antibody $(1 \mu \mathrm{g} / \mathrm{ml})$ in the blocking buffer for $1 \mathrm{hr}$, washed with TBST, and incubated with a secondary antibody conjugated with alkaline phosphatase (Promega) in the blocking buffer. After washing, a chromogenic reaction was carried out.

\section{Cell culture, growth arrest, and transformation}

Mouse cell lines NIH-3T3 (Jainchill et al. 1969) and N18 (Amano et al. 1972) and human cell lines HeLa (Gey et al. 1952) and SiHa (Friedl et al. 1970) were cultured in Dulbecco's modified Eagle's medium (DMEM) supplemented with 10\% fetal calf serum (FCS). For growth-arrest experiments, NIH-3T3 cells were cultured for 10 days in DMEM with $0.2 \%$ FCS, and primary uterine fibroblasts or $\mathrm{SiHa}$ cells were maintained in a medium with $0.5 \%$ FCS for 7 days (low serum) or in regular growth medium for 7 days after reaching confluency (high density) (Masui et al. 1995).

Rat embryo fibroblast cell line CREF (Fisher et al. 1982) was cotransfected with the vectors pUHD10-3 /Gossen and Bujard 1992) harboring ras $^{\mathrm{G} 12 \mathrm{~V}}$ and pUHD15-1 neo (Resnitzky et al. 1994). A G418-resistant clone exhibiting an untransformed phenotype in medium containing $1 \mu \mathrm{g} / \mathrm{ml}$ of tetracycline hydrochloride and a transformed phenotype in the regular medium was isolated (see below).

\section{Microinjection}

HeLa cells in late anaphase to early telophase were microinjected with either antibodies 6 or $11(0.1 \mathrm{mg} / \mathrm{ml})$ or the preimmune serum from the animal used for antibody 6 dialyzed with PBS ( $\mathrm{pH} \mathrm{7.32)} \mathrm{using} \mathrm{a} \mathrm{microinjection} \mathrm{system} \mathrm{(Eppendorf)} \mathrm{with}$ 
maintenance pressure $\left(P_{2}\right)=300-350 \mathrm{hPa}$, injection pressure $\left(P_{3}\right)=30-35 \mathrm{hPa}$ for $0.1 \mathrm{sec}$. The cells were observed with a phase-contrast microscope at $37^{\circ} \mathrm{C}$ for up to $3 \mathrm{hr}$.

Similarly, HeLa cells in interphase were microinjected with 2 mM GTP $y$ S (Sigma) in PBS or $40 \mu \mathrm{g} / \mathrm{ml}$ of C3 ADP-ribosyl transferase (a gift from Dr. Shuh Narumiya, Kyoto University, Japan) in PBS with $0.5 \mu \mathrm{g} / \mathrm{ml}$ of dextran-Texas Red (Molecular Probes) with $P_{2}=600-700 \mathrm{hPa}, P_{3}=50 \mathrm{hPa}$ for $0.1 \mathrm{sec}$. The cells were incubated for $1 \mathrm{hr}$ until fixation.

$\mathrm{NIH}+3 \mathrm{~T} 3$ cells cultured in serum starved condition for 10 days (see above) were microinjected with antibody $6(0.1 \mathrm{mg} / \mathrm{ml}$ ) with injection parameters of $P_{2}=500 \mathrm{hPa}, P_{3}=50 \mathrm{hPa}$ for 0.1 $\mathrm{sec}$, incubated for $10 \mathrm{~min}$, and then stimulated with DMEM containing $10 \%$ FCS. The cells were subsequently incubated for 10 min until fixation.

\section{Immunocytochemistry}

The cells were fixed with $3.7 \%$ formaldehyde in PBS for $5 \mathrm{~min}$, treated with $0.1 \%$ Triton X-100 in PBS for 5 min, incubated in a blocking buffer (1\% BSA in PBS) for $1-6 \mathrm{hr}$ and then with antibody $11(1 \mu \mathrm{g} / \mathrm{ml})$ in the blocking buffer for $1 \mathrm{hr}$, washed with PBS, and incubated for $1 \mathrm{hr}$ with FITC- or Texas Redlabeled anti-rabbit IgG (Molecular Probes, 1:100) with or without BODIPY 581/591 phalloidin (Molecular Probes, $1 \mu \mathrm{l} / \mathrm{ml}$ ). Anti-tubulin antibody TAT1 (Woods et al. 1989) (1 $\mu \mathrm{g} / \mathrm{ml}$ ), antivinculin antibody (Sigma, 1:200), and secondary antibodies against mouse IgG labeled with Texas Red or Cy-5 (Jackson, $1: 100$ ) were additionally used for multiple staining. After washing with PBS, the samples were incubated with Hoechst 33342 $(0.5 \mu \mathrm{g} / \mathrm{ml})$ for $10 \mathrm{~min}$, overlaid with glycerol, and observed as follows.

\section{Fluorescence microscopy and image processing}

The details have been described previously (Hiraoka et al. 1991; Haraguchi et al. 1997). In brief, fluorescence images were obtained through a microscope (IMT-2 or IX-70, Olympus) with an oil immersion objective lens [SPlanApo $60 \mathrm{UV}(\mathrm{NA}=1.4)$ or DPlanApo 40 UV $(\mathrm{NA}=1.0)$ for IMT-2, UApo $40(\mathrm{NA}=1.35)$ for IX-70, Olympus] and high-selectivity filters for DAPI, fluorescein, Texas Red, and Cy-5 (Chroma Technology) on a Peltiercooled, charge-coupled device (KAF1400, Photometrics). Serial optical section data $(0.5 \mu \mathrm{m}$ step $\times 15-30$ focal planes $)$ for Nedd5, DNA, $\alpha$-tubulin, or F actin were collected and computationally processed by use of a three-dimensional deconvolution method (Agard et al. 1989).

\section{Synthesis of GST-Nedd5 fusion proteins and GTPase assay}

To obtain G47V, K50E, S51N, and Q125L mutants of Nedd5, site-directed mutagenesis (Kunkel et al. 1987) was performed on N5.2.8 with oligonucleotides 5'-GTTGGTGAATCTGTTCTAGGAAAA， 5'-TCTGGTCTAGGAGAATCAACTCTC, 5'TTATGAGAGTGTTTTTTCCTAGACCAG, and 5'-GCGTTCAAACAGCTCATCAATG, respectively. cDNAs were cloned into a bacterial expression vector, pGEX3T-2 (Pharmacia), and the recombinant GST-Nedd5 fusion proteins were purified with glutathione-agarose (Sigma). The molecular weights of the fusion proteins and their immunoreactivities were confirmed by immunoblot assays using antibodies 6 and 11. The GTPase assay was performed by the method of Gibbs et al. (1988) with some modification. In brief, $4 \mathrm{nM}\left[\gamma^{-32} \mathrm{P}\right] \mathrm{GTP}$ (5000 $\mathrm{Ci} / \mathrm{mmole}$, Amersham) or $10 \mathrm{nM}\left[\gamma^{-{ }^{35}} \mathrm{~S}\right] \mathrm{GTP} \gamma \mathrm{S}(1500 \mathrm{Ci} /$ mmole, Du Pont/NEN) was mixed with each protein $(\sim 100 \mathrm{nM})$ attached to the beads in ice-cold reaction buffer containing 20 $\mathrm{mm}$ Tris- $\mathrm{HCl}(\mathrm{pH} 8.0), 5 \mathrm{~mm} \mathrm{MgCl}, 100 \mathrm{~mm} \mathrm{NaCl}, 10 \mathrm{~mm}$ 2-mercaptoethanol, $10 \%$ (vol/vol) glycerol, and $100 \mu \mathrm{g} / \mathrm{ml}$ of BSA with $10 \mathrm{~mm}$ EDTA in a total volume of $200 \mu \mathrm{l}$. After brief centrifugation, the buffer was exchanged to $200 \mu \mathrm{l}$ of ice-cold reaction buffer without EDTA, and incubated at $37^{\circ} \mathrm{C}$ for up to $20 \mathrm{~min}$. The reaction was stopped by washing the beads with ice-cold reaction buffer without EDTA and the radioactivity of the bound $\left[\gamma^{32} \mathrm{P}\right] \mathrm{GTP}$ or $\left[\gamma^{-35} \mathrm{~S}\right] \mathrm{GTP} \gamma \mathrm{S}$ was measured. Effects of antibodies were tested by incubating the fusion proteins with antibody 6 or 11 at $37^{\circ} \mathrm{C}$ for $30 \mathrm{~min}$ before mixing with $\left[\gamma^{-32}\right.$ P $]$ GTP.

\section{Expression and detection of Nedd5-GFP fusion protein}

Wild-type and the four mutant Nedd5 cDNAs were cloned into the phGFP-S65T vector (Clontech) and HeLa and NIH-3T3 cells were transfected with the various constructs using Lipofectamine (GIBCO-BRL) or Superfect (Qiagen). Cells expressing either of the five fusion proteins were observed after $16-48 \mathrm{hr}$ with or without Hoechst 33342 staining. Behavior of the Nedd5-GFP in the transfectants was examined by sequential fluorescence image collection at every $20 \mathrm{sec}$ for up to $0.6 \mathrm{hr}$. After live observation, the cells were fixed for immunocytochemistry.

\section{Immunoelectron microscopy}

Ultrastructural observation of Nedd5 was performed using the pre-embedding, gold particle-silver enhancement method (Burry et al. 1992; Mizoguchi et al. 1994). In brief, the cells were fixed with $4 \%$ paraformaldehyde, $0.05 \%$ tannic acid, and $10 \mu \mathrm{M}$ phenylmethylsulfonyl fluoride in PBS for $4 \mathrm{hr}$, blocked with $5 \%$ BSA and $0.02 \%$ saponin in PBS for $10 \mathrm{~min}$, and incubated with antibody $11(1 \mu \mathrm{g} / \mathrm{ml})$ in $1 \%$ BSA/PBSS $\{0.005 \%$ saponin in PBS $)$ for $24 \mathrm{hr}$. The cells were washed with PBSS, incubated with a secondary antibody labeled with 1-nm gold particles, Nanogold (Nanoprobes, 1:100), in 1\% BSA/PBSS for $2 \mathrm{hr}$, washed with PBSS, and fixed with $1 \%$ glutaraldehyde in PBS for $10 \mathrm{~min}$. After enhancement with HQ silver (Nanoprobes), the cells were postfixed with $0.8 \% \mathrm{OsO}_{4}$ for $50 \mathrm{~min}$, dehydrated, and embedded in epoxy resin. Ultrathin serial sections were stained with uranyl acetate and lead citrate and examined with an electron microscope, JEM1200EX (Nihon Denshi).

\section{Acknowledgments}

We are grateful to Dr. J.R. Pringle for providing the yeast mutants and Dr. K. Matsumoto for advice in the complementation experiments. We also thank Drs. M. Nishizawa, T. Masui, Y. Yamamura, J. Miyazaki, F. Matsumura, H. Sabe, S. Hattori, K. Umesono, H. Bujard, Y. Honda, K. Kato, E. Nishida, Y. Saitoh, S. Narumiya, T. Obinata, I. Mabuchi, and T.J. Mitchison for providing materials, helpful discussions and/or encouragement; Dr. D.B. Alexander for critical reading of the manuscript; Mr. T. Kaneda (Olympus Optical Co. Ltd.) for technical help in microscopy; Ms. T. Koujin and N. Tachibana for technical help in cell cultures; Ms. A. Miyazaki and M. Okamoto for secretarial assistance; and other members of our laboratories for technical help and suggestions. This work was supported in part by Grantin-Aid from the Ministry of Education, Science and Culture (M.K. and M.N.) and Ministry of Posts and Telecommunications (T.H. and Y.H.) of Japan and Wellcome Trust Senior Research Fellowship in Medical Sciences (S.K.). The early part of this work was carried out in RIKEN and Cancer Institute, the Japanese Foundation for Cancer Research. 
The publication costs of this article were defrayed in part by payment of page charges. This article must therefore be hereby marked "advertisement" in accordance with 18 USC section 1734 solely to indicate this fact.

\section{References}

Agard, D.A., Y. Hiraoka, P. Shaw, and J.W. Sedat. 1989. Fluorescence microscopy in three dimensions. Methods Cell Biol. 30: 353-377.

Amano, T., E. Richelson, and M. Nirenberg. 1972. Neurotransmitter synthesis by neuroblastoma clones. Proc. Natl. Acad. Sci. 69: 258-263.

Bourne, H.R., D.A. Sanders, and F. McCormick. 1991. The GTPase superfamily: Conserved structure and molecular mechanism. Nature 349: 117-127.

Burridge, K., K. Fath, T. Kelly, G. Nuckolls, and C. Turner. 1988. Focal adhesions: Transmembrane junctions between the extracellular and the cytoskeleton. Annu. Rev. Cell Biol. 4: $487-525$.

Burry, R.W., D.D. Vandre, and D.M. Hayes. 1992. Silver enhancement of gold antibody probes in pre-embedding electron microscopic immunocytochemistry. $\%$. Histochem. $C y$ tochem. 40: 1849-1856.

Byers, B. 1981. Cytology of the yeast life cycle. In The molecular biology of the yeast Saccharomyces: Life cycle and inheritance (ed. J.N. Strathern, E.W. Jones, and J.R. Broach), vol. 1, pp. 59-96. Cold Spring Harbor Laboratory, Cold Spring Harbor, New York, NY.

Byers, B. and L. Goetsch. 1976. A highly ordered ring of membrane-associated filaments in budding yeast. I. Cell Biol. 69: 717-721.

Chant, J. 1996. Septin scaffolds and cleavage planes in Saccharomyces. Cell 84: 187-190.

Chou, P.Y. and G.D. Fasman. 1978. Empirical predictions of protein conformation. Annu. Rev. Biochem. 47: 251-276.

Cooper, J.A. and D.P. Kiehart. 1996. Septins may form a ubiquitous family of cytoskeletal filaments. I. Cell Biol. 134: 1345-1348.

Cowan, N.J., P.R. Dobner, E.V. Fuchs, and D.W. Cleveland. 1983. Expression of human alpha-tubulin genes: Interspecies conservation of $3^{\prime}$ untranslated regions. Mol. Cell. Biol. 3: $1738-1745$.

Fares, H., M. Peifer, and J.R. Pringle. 1995. Localization and possible functions of Drosophila septins. Mol. Biol. Cell 6: 1843-1859.

Fares, H., L. Goetsch, and J.R. Pringle. 1996. Identification of a developmentally regulated septin and involvement of the septins in spore formation in Saccharomyces cerevisiae. $I$. Cell Biol. 132: 399-411.

Field, C.M., O. Al-Awar, J. Rosenblatt, M.L. Wong, B.M. Alberts, and T.J. Mitchison. 1996. A purified Drosophila septin complex forms filaments and exhibits GTPase activity. $I$. Cell Biol. 133: 605-616.

Fisher, P.B., L.E. Babiss, I.B. Weinstein, and H.S. Ginsberg. 1982. Analysis of type 5 adenovirus transformation with a cloned rat embryo cell line (CREF). Proc. Natl. Acad. Sci. 79: $3527-$ 3531.

Flescher, E.G., K. Madden, and M. Snyder. 1993. Components required for cytokinesis are important for bud site selection in yeast. I. Cell Biol. 122: 373-386.

Ford, S.K. and J.R. Pringle. 1991. Cellular morphogenesis in the Saccharomyces cerevisiae cell cycle: Localization of the $C D C 11$ gene product and the timing of events at the budding site. Dev. Genet. 12: 281-292.
Friedl, F., I. Kimura, T. Osato, and Y. Ito. 1970. Studies on a new human cell line $(\mathrm{SiHa})$ derived from carcinoma of uterus. I. Its establishment and morphology. Proc. Soc. Exp. Biol. Med. 135: 543-545.

Gey, G.O., W.D. Coffman, and M.T. Kubicek. 1952. Tissue culture studies of the proliferative capacity of cervical carcinoma and normal epithelium. Cancer Res. 12: 364-365.

Gibbs, J.B., M.D. Schaber, W.J. Allard, I.S. Sigal, and E.M. Scolnik. 1988. Purification of ras GTPase activating protein from bovine brain. Proc. Natl. Acad. Sci. 85: 5026-5030.

Gossen, M. and H. Bujard. 1992. Tight control of gene expression in mammalian cells by tetracycline-responsive promoters. Proc. Natl. Acad. Sci. 89: 5547-5551.

Haarer, B.K. and J.R. Pringle. 1987. Immunofluorescence localization of the Saccharomyces cerevisiae CDC12 gene product to the vicinity of the 10-nm filaments in the mother-bud neck. Mol. Cell. Biol. 7: 3678-3687.

Haraguchi, T., T. Kaneda, and Y. Hiraoka. 1997. Dynamics of chromosomes and microtubules visualized by multiplewavelength fluorescence imaging in living mammalian cells: Effect of mitotic inhibitors on cell cycle progression. Genes to Cells (in press).

Hartwell, L.H. 1971. Genetic control of the cell division cycle in yeast. IV. Genes controlling bud emergence and cytokinesis. Exp. Cell Res. 69: 265-276.

Hiraoka, Y., J.R. Swedlow, M.R. Paddy, D.A. Agard, and J.W. Sedat. 1991. Three-dimensional multiple-wavelength fluorescence microscopy for the structural analysis of biological phenomena. Semin. Cell Biol. 2: 153-165.

Jainchill, J.L., S.A. Aaronson, and G.J. Todaro. 1969. Murine sarcoma and leukemia viruses: Assay using clonal lines of contact-inhibited mouse cells. I. Virol. 4: 549-553.

Kato, K. 1990. A collection of cDNA clones with specific expression patterns in mouse brain. Eur. J. Neurosci. 2: 704711.

1992. Finding new genes in the nervous system by cDNA analysis. Trends Neurosci. 15: 319-323.

Kim, H.B., B.K. Haarer, and J.R. Pringle. 1991. Cellular morphogenesis in the Saccharomyces cerevisiae cell cycle: Localization of the $C D C 3$ gene product and the timing of events at the budding site. J. Cell Biol. 112: 535-544.

Kishi, K., T. Sasaki, S. Kuroda, T. Itoh, and Y. Takai. 1993. Regulation of cytoplasmic division of Xenopus embryo by rho 21 and its inhibitory GDP/GTP exchange protein (rho GDI). I. Cell Biol. 120: 1187-1195.

Kozak, M. 1986. An analysis of 5'-noncoding sequences from 699 vertebrate messenger RNAs. Nucleic Acids Res. 15: 8125-8132.

Kumar, S., Y. Tomooka, and M. Noda. 1992. Identification of a set of genes with developmentally down-regulated expression in the mouse brain. Biochem. Biophys. Res. Commun. 185: 1155-1161.

Kumar, S., M. Kinoshita, M. Noda, N.G. Copeland, and N.A. Jenkins. 1994. Induction of apoptosis by the mouse Nedd2 gene, which encodes a protein similar to the product of the Caenorhabditis elegans cell death gene ced-3 and the mammalian IL-1 $\beta$-converting enzyme. Genes \& Dev. 8: $1613-1626$.

Kunkel, T.A., J.D. Roberts, and R.A. Zakour. 1987. Rapid and efficient site-directed mutagenesis without phenotypic selection. Methods Enzymol. 154: 367-382.

Lee, N.H., K.G. Weinstock, E.F. Kirkness, J.A. Earle-Hughes, R.A. Fuldner, S. Marmaros, A. Glodek, J.D. Gocayne, M.D. Adams, A.R. Kerlavage, C.M. Fraser, and J.C. Venter. 1995. Comparative expressed-sequence-tag analysis of differential gene expression profiles in PC- 12 cells before and after nerve 
growth factor treatment. Proc. Natl. Acad. Sci. 92: 83038307.

Longtine, M.S., D.J. Demarini, M.L. Valencik, O.S. Al-Awar, H. Fares, C. De Virgilio, and J.R. Pringle. 1996. The septins: Roles in cytokinesis and other processes. Curr. Opin. Cell Biol. 8: 106-119.

Lupas, A., M. van Dyke, and J. Stock. 1991. Predicting coiled coils from protein sequences. Science 252: 1162-1164.

Mabuchi, I., Y. Hamaguchi, H. Fujimoto, N. Morii, M. Mishima, and S. Narumiya. 1993. A rho-like protein is involved in the organisation of the contractile ring in dividing sand dollar eggs. Zygotes 1: 325-331.

Machesky, L.M. and A. Hall. 1996. Rho: A connection between membrane receptor signalling and the cytoskeleton. Trends Cell Biol. 6: 304-310.

Masui, T. 1995. Establishment of an outgrowth culture system to study growth regulation of normal human epithelium. In Vitro Cell Dev. Biol. Anim. 31: 440-446.

Mizoguchi, A., Y. Yano, H. Hamaguchi, H. Yanagida, C. Ide, A. Zahraoui, H. Shirataki, T. Sasaki, and Y. Takai. 1994. Localization of Rabphilin-3A on the synaptic vesicle. Biochem. Biophys. Res. Commun. 202: 1235-1243.

Nagase, T., N. Seki, A. Tanaka, K. Ishikawa, and N. Nomura. 1995. Prediction of the coding sequences of unidentified human genes. IV. The coding sequences of 40 new genes (KIAA0121-KIAA0160) deduced by analysis of cDNA clones from human cell line KG-1. DNA Res. 2: 167-174.

Nakatsuru, S., K. Sudo, and Y. Nakamura. 1994. Molecular cloning of a novel human cDNA homologous to CDC10 in Saccharomyces cerevisiae. Biochem. Biophys. Res. Commun. 202: 82-87.

Neufeld, T.P. and G.M. Rubin. 1994. The Drosophila peanut gene is required for cytokinesis and encodes a protein similar to yeast putative bud neck filament proteins. Cell 77:371379.

Niwa, H., K. Yamamura, and J. Miyazaki. 1991. Efficient selection for high-expression transfectants with a novel eukaryotic vector. Gene 108: 193-199.

Nobes, C. and A. Hall. 1995. Rho, rac and CDC42 GTPases regulate the assembly of multimolecular focal complexes associated with actin stress fibers, lamellipodia and filopodia. Cell 81: 53-62.

Nottenburg, C., W.M. Gallatin, and T. St. John. 1990. Lymphocyte HEV adhesion variants differ in the expression of multiple gene sequences. Gene 95: 279-284.

Polakis, P. and F. McCormick. 1993. Structural requirements for the interaction of $21^{\text {ras }}$ with GAP, exchange factors and its biological effector target. J. Biol. Chem. 268: 9157-9160.

Pringle, J.R. and L.H. Hartwell. 1981. The Saccharomyces cerevisiae cell cycle. In The molecular biology of the yeast Saccharomyces: Life cycle and inheritance led. J.N. Strathern, E.W. Jones, and J.R. Broach), vol. 1, pp. 97-142. Cold Spring Harbor Laboratory, Cold Spring Harbor, NY.

Redmond, T., M. Tardif, and S.H. Zigmond. 1994. Induction of actin polymerization in permeabilized neutrophils. Role of ATP. J. Biol. Chem. 269: 21657-21663.

Resnitzky, D., M. Gossen, H. Bujard, and S.I. Reed. 1994. Acceleration of the $G_{1} / S$ phase transition by expression of cyclins D1 and E with an inducible system. Mol. Cell. Biol. 14: $1669-1679$.

Ridley, A.J. and A. Hall. 1992. The small GTP-binding protein rho regulates the assembly of focal adhesions and actin stress fibers in response to growth factor. Cell 70: 389-399.

Sambrook, J., E.F. Fritsch, and T. Maniatis. 1989. Molecular cloning: A laboratory manual, 2nd ed. Cold Spring Harbor Laboratory Press, Cold Spring Harbor, NY.
Saraste, M., P.R. Sibbald, and A. Wittinghofer. 1990. The P-loop: A common motif in ATP- and GTP-binding proteins. Trends Biochem Sci. 15: 430-434.

Sazuka, T., M. Kinoshita, Y. Tomooka, Y. Ikawa, M. Noda, and S. Kumar. 1992. Expression of DRG during murine embryonic development. Biochem. Biophys. Res. Commun. 189: 371-377.

Tam, J.P. 1988. Synthetic peptide vaccine design: Synthesis and properties of a high-density multiple antigenic peptide system. Proc. Natl. Acad. Sci. 85: 5409-5413.

Tso, J.Y., X.H. Sun, T.H. Kao, K.S. Reece, and R. Wu. 1985 Isolation and characterization of rat and human glyceraldehyde-3-phosphate dehydrogenase cDNAs: Genomic complexity and molecular evolution of the gene. Nucleic Acids Res. 13: 2485-2502.

Wilson, T. and R. Treisman. 1988. Removal of poly(A) and consequent degradation of c-fos mRNA facilitated by $3^{\prime}$ AU-rich sequences. Nature 336: 396-399.

Woods, A., T. Sherwin, S. Rosemary, T.H. MacRae, A.J. Baines, and K. Gull. 1989. Definition and individual components within the cytoskeleton of Trypanosoma brucei by a library of monoclonal antibodies. J. Cell Sci. 93: 491-500. 


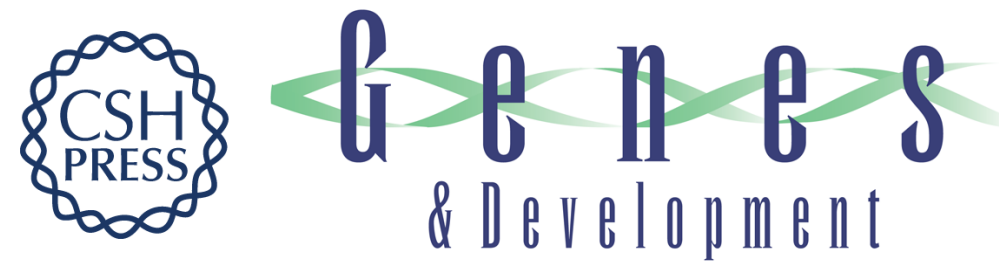

\section{Nedd5, a mammalian septin, is a novel cytoskeletal component interacting with actin-based structures.}

M Kinoshita, S Kumar, A Mizoguchi, et al.

Genes Dev. 1997, 11:

Access the most recent version at doi:10.1101/gad.11.12.1535

References This article cites 55 articles, 22 of which can be accessed free at:

http://genesdev.cshlp.org/content/11/12/1535.full.html\#ref-list-1

License

Email Alerting

Service

Receive free email alerts when new articles cite this article - sign up in the box at the top right corner of the article or click here.

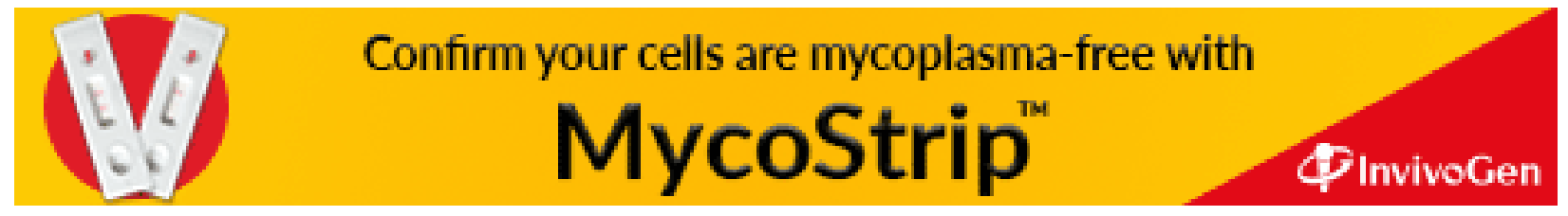

